\title{
20. MINERALIZATION AND TRACE ELEMENT VARIATION IN DEEP-SEA PELAGIC SEDIMENTS OF THE WHARTON BASIN, INDIAN OCEAN
}

\author{
Anthony C. Pimm, Scripps Institution of Oceanography, La Jolla, California
}

\section{INTRODUCTION}

Several features of the cores recovered from Leg 22 indicated varying degrees and kinds of mineralization in pelagic sediments. The nature of this mineralization could not be resolved by the routine microscopic examination of smear slides onboard the ship. It was therefore decided to use analytical methods to investigate vertical variations in the chemical composition of the three sites $(211,212,213)$ drilled in the Wharton Basin (Figure 1). In particular, the main features of interest which were to be investigated included:

1) basal iron-oxide facies (Sites 211, 212, 213)

2) possible effects of intrusion of sill (Site 211)

3) chemistry of reduced zones in clay adjacent to chalk units (Site 212)

4) dark banding in siliceous oozes (Site 213)

$5)$ trace element composition of typical brown clays (Sites 211, 212, 213).

\section{METHODS OF INVESTIGATION}

Using the visual core descriptions made onboard ship, 58 samples were selected for a rapid reconnaissance study using the X-ray fluorescence technique of Fitzgerald and Gantzel (1971). Photographs of the energy dispersion spectra for each sample were compared with U.S.G.S. standard W1, and a semiquantitative estimate of the relative abundance of various elements was made by directly comparing the peak heights. For the analysis of $\mathrm{Fe}$ and $\mathrm{Mn}$ the samples were counted for 100 -sec intervals, but for the trace elements counts over 30 -min intervals were necessary. Photographs of all the energy dispersion spectra obtained during this study are stored with the Curator of the Deep Sea Drilling Project, La Jolla, California.

Based on the results of this preliminary study, 28 of the original 58 samples, which showed higher values (compared with W1) of one or more elements (Table 1), were prepared for atomic absorption analysis. This analysis was carried out on a Perkin-Elmer 403 Atomic Absorption Spectrophotometer using the digital concentration readout. For $\mathrm{Ni}, \mathrm{Cu}, \mathrm{Pb}, \mathrm{Zn}, \mathrm{Mn}, \mathrm{Fe}$, and $\mathrm{Cr}$ an air-acetylene flame was used with the standard burner head (4 in, single slot); for $\mathrm{V}$ and $\mathrm{Ti}$ a nitrous-oxide acetylene flame was used with the nitrous-oxide burner head $(5 \mathrm{~cm}$, single slot). Suggested Perkin-Elmer standard conditions and instrument settings were followed, except that the burner head was set perpendicular to the light path in the analysis for $\mathrm{Mn}$ and $\mathrm{Fe}$ because of the high sensitivity of the instrument to these elements. Also, the Perkin-Elmer Deuterium-Arc background corrector was used in the Ni determination.
All dried and ground samples were weighed to $0.5 \mathrm{~g}$, placed in Teflon decomposition bombs, and wetted with distilled water. Approximately $1 \mathrm{ml}$ of concentrated aqua $\left(3 \mathrm{HCl}: 1 \mathrm{HNO}_{3}\right)$ was added to the samples, and then $6 \mathrm{ml}$ of concentrated HF was added. The vessels were then tightly covered and placed in the oven for $1 \mathrm{hr}$ at $110^{\circ} \mathrm{C}$. When cooled, samples were transferred to $50-\mathrm{ml}$ polyethylene volumetric flasks and diluted to the mark with a solution of distilled water and $\sim 2.2 \mathrm{~g}$ boric acid. The solutions were then mixed and stored in polyethylene bottles.

Standards were prepared from commercial $1000 \mathrm{ppm}$ solutions to the following concentrations:

$$
\begin{array}{llll}
\mathrm{Cr} & 2.0,1.0,0.5 \mathrm{ppm} & \mathrm{Pb} & 5,2,1 \mathrm{ppm} \\
\mathrm{V} & 2.0,1.0,0.5 \mathrm{ppm} & \mathrm{Zn} & 2.0,1.0,0.5 \mathrm{ppm} \\
\mathrm{Ti} & 100,50,10 \mathrm{ppm} & \mathrm{Mn} & 100,50,10 \mathrm{ppm} \\
\mathrm{Ni} & 10,5,4,2,1 \mathrm{ppm} & \mathrm{Fe} & 100,50,10 \mathrm{ppm} \\
\mathrm{Cu} & 5,2,1 \mathrm{ppm} & &
\end{array}
$$

A set of U.S.G.S. standards was prepared and analyzed using the same instrument setup and method of preparation as for the samples. The values obtained agreed with the reported range of values for the U.S.G.S. standards, with one exception. The nickel values obtained were much higher than the reported range of values, but when the $D_{2}$ background correcter was used the results were within the reported range. Hence, it was concluded that the D2 background corrector removed interferences for $\mathrm{Ni}$, and the sediment samples were rerun using this corrector. The element concentration values obtained and the reported range of values for the U.S.G.S. standards W1, G2, and BCR-1 are given in Table 2.

Ranges of error are recorded in Table 2 for each element. The error was determined by choosing random, duplicate samples and weighing, decomposing, and analyzing these samples along with the others and by comparing the difference between duplicate samples.

\section{RESULTS AND DISCUSSION}

The results of the reconnaissance semiquantitative analysis are given in Table 1 and of the detailed quantitative analysis of some of these same samples in Table 2. Most of the samples in the latter analysis are from Sites 212 and 213 , and downhole plots of the results against lithology are shown in Figures 2 and 3, respectively.

In addition, some further analytical results were generously made available by R. Hekinian. These are major element analysis of nine sediment samples selected from Sites 211, 212, and 213 (Table 3) and trace element analysis of four igneous rock samples from Sites 211 and 213 (Table 4). 


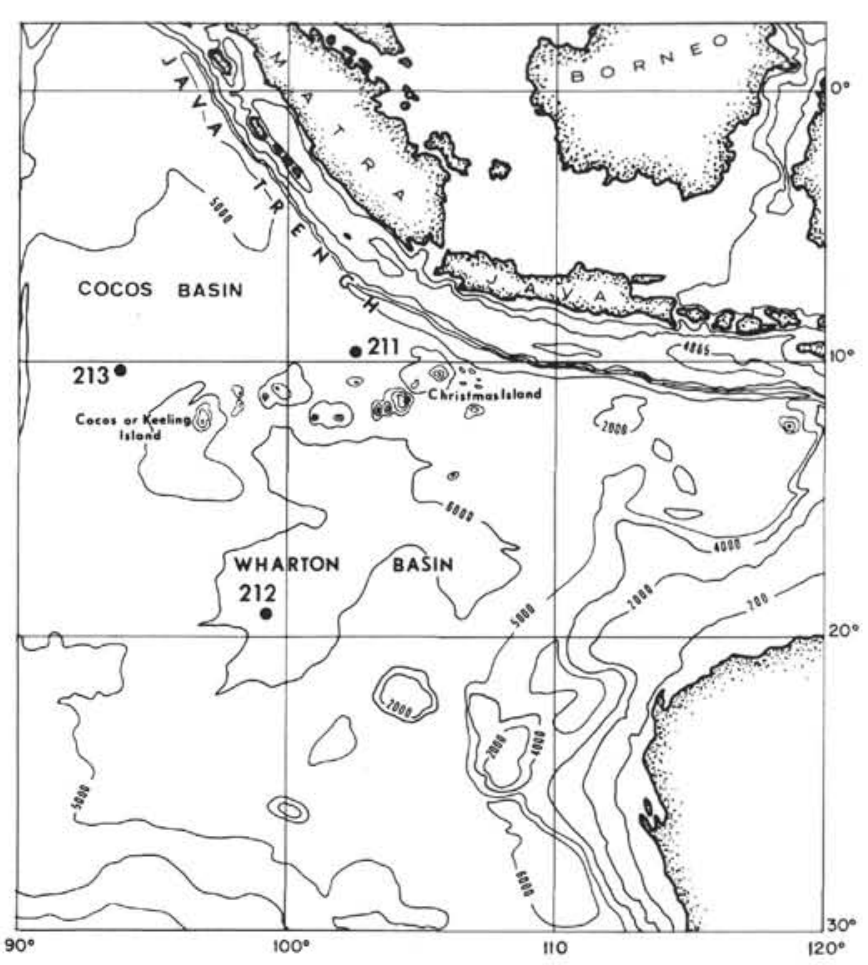

Figure 1. Location of DSDP Leg 22 sites in Wharton Basin.

\section{Basal Iron-Oxide Facies}

Many sites drilled during the course of the Deep Sea Drilling Project have shown the presence of an iron-oxideenriched sediment facies at the base of the sediment column immediately overlying basalts, which were presumed to have been generated from a mid-oceanic ridgetype spreading center. Descriptions of these iron-rich facies have been given by Peterson et al. (1970, p. 421), von der Broch and Rex (1970), von der Borch et al. (1971), Drever (1971), Lancelot et al. (1972, pp. 911-916), and Cronan (1973).

The iron-oxide-rich facies in Leg 22 sites was recognized on the basis of color and an abundance of iron-oxide-rich clayey aggregates and high relief grains seen in smear slides. Visual estimates show that the iron-oxide-rich clayey aggregates make up at least $15 \%$ and may range as high as $80 \%$ in places of the sediment. At Sites 212 and 213 the iron-oxide facies is about 30 and 40 meters thick, respectively (Figures 2 and 3). However, the analyses show that only the lowermost sample (probably within 5 meters of the basalt) in each site contained more than $10 \%$ total iron. Samples higher in this facies did not contain significantly greater (i.e., more than double) amounts of total iron normally present in more typical pelagic brown clays much higher in the succession.

Major element analyses (Table 3) confirm the existence of an iron-rich basal facies at Site 212 , Core 38 and Site 213 , Core 16. It should be noted that if the analyses were recalculated on a dry weight basis, the $\mathrm{Fe}_{2} \mathrm{O}_{3}$ content would be higher than that shown in Table 3. The $\mathrm{Fe}_{2} \mathrm{O}_{3}$ major element and $\mathrm{Fe}$ element analyses made by different laboratories and techniques show a good agreement: for example, the higher iron content at Site 213 than 212 and
TABLE 1

Semiquantitative X-Ray Fluorescence Analyses

\begin{tabular}{|c|c|c|c|c|c|c|c|c|}
\hline $\begin{array}{l}\text { Lab P. } \\
\text { No. }\end{array}$ & $\begin{array}{l}\text { Core, } \\
\text { Section, } \\
\text { Interval } \\
(\mathrm{cm})\end{array}$ & $\mathrm{Ni}$ & $\mathrm{Cu}$ & $\mathrm{Zn}$ & $\mathrm{Pb}$ & $\mathrm{Mn}$ & $\mathrm{Fe}$ & $\begin{array}{l}\text { Other } \\
\text { Elements }\end{array}$ \\
\hline \multicolumn{9}{|c|}{ Site 211} \\
\hline 1 & $1-1,14-16$ & + & $=$ & + & $=$ & + & - & \\
\hline 2 & $10-\mathrm{CC}$ & + & $=$ & + & $=$ & - & $=$ & \\
\hline 3 & $11-\mathrm{CC}$ & $=$ & $=$ & + & $=$ & - & $=$ & \\
\hline 4 & $11-\mathrm{CC}$ & - & - & + & $=$ & - & - & \\
\hline 5 & $12-1,11-13$ & $=$ & $=$ & + & $=$ & - & - & \\
\hline 6 & $12-2,122-124$ & + & - & $=$ & $=$ & - & - & \\
\hline 7 & $12-2,136-138$ & - & - & + & $=$ & - & - & \\
\hline 8 & $13-1,68-69$ & $=$ & $=$ & + & $=$ & - & $=$ & \\
\hline 9 & $13-1,69-70$ & $=$ & $=$ & + & $=$ & - & - & \\
\hline 10 & $13-1,138-139$ & $=$ & $=$ & + & $=$ & - & - & \\
\hline 11 & $14-1,18-20$ & $=$ & $=$ & + & $=$ & - & - & \\
\hline 12 & $14-1,28-30$ & $=$ & $=$ & + & $=$ & - & - & \\
\hline 13 & $14-1,61-63$ & $=$ & - & $=$ & $=$ & - & - & \\
\hline 14 & $15-1,118-120$ & $=$ & $=$ & + & $=$ & - & + & $\mathrm{Zr}+\mathrm{Sr}+$ \\
\hline \multicolumn{9}{|c|}{ Site 212} \\
\hline 15 & $2-1,114-116$ & + & + & + & $=$ & + & + & \\
\hline 16 & $2-3,111-113$ & + & + & + & $=$ & + & - & \\
\hline 17 & $4-1,122-123$ & + & $=$ & + & ++ & + & - & \\
\hline 18 & $10-1,32-33$ & + & + & + & + & + & - & \\
\hline 19 & $10-2,84-86$ & - & - & $=$ & $=$ & - & - & $\mathrm{Sr}^{+}$ \\
\hline 20 & $10-4,79-80$ & $=$ & - & $=$ & $=$ & - & - & $\mathrm{Sr}+$ \\
\hline 21 & $15-1,63$ & ++ & ++ & $=$ & $=$ & - & $=$ & $\mathrm{Rb}+\mathrm{Sr}=$ \\
\hline 22 & $15-1,67-68$ & + & + & + & + & - & + & $\mathrm{Sr}=$ \\
\hline 23 & $15-1,97-100$ & + & + & + & ++ & + & + & $\mathrm{Sr}=$ \\
\hline 24 & $16-2$ & + & + & + & + & + & + & \\
\hline 25 & $18-2,5-6$ & + & $=$ & + & + & + & + & \\
\hline 26 & $23-5,105-107$ & $=$ & ++ & + & - & - & - & \\
\hline 27 & $26-2,81-82$ & - & - & + & $=$ & - & - & $\mathrm{Sr}^{+}$ \\
\hline 28 & $27-1,102-104$ & $=$ & $=$ & + & H & - & - & $\mathrm{Sr}=$ \\
\hline 29 & $27-1,128-130$ & ++ & + & + & ++ & - & - & $\mathrm{Rb}+$ \\
\hline 30 & $27-4,31-32$ & $=$ & + & + & + & - & - & \\
\hline 31 & $27-6,66-68$ & $=$ & $=$ & + & $=$ & - & - & \\
\hline 32 & $28-1,55-57$ & $=$ & $=$ & + & $=$ & - & - & $\mathrm{Cr}=$ \\
\hline 33 & $28-1,61$ & + & + & + & $=$ & - & - & \\
\hline 34 & $29-1,57$ & $=$ & $=$ & + & $=$ & - & - & $\mathrm{Cr}+$ \\
\hline 35 & $29-1,71$ & + & + & + & + & - & - & \\
\hline 36 & $35-3,80-82$ & $=$ & $=$ & $=$ & - & - & - & $\mathrm{Sr}^{+}$ \\
\hline 37 & $35-4,80-82$ & $=$ & $=$ & + & - & - & - & $\mathrm{Sr}+$ \\
\hline 38 & $35-5,10-12$ & $=$ & + & + & $=$ & - & - & $\mathrm{Sr}=\mathrm{Cr}=$ \\
\hline 39 & $35-5,40-42$ & $=$ & + & + & $=$ & - & - & $\mathrm{Cr}=$ \\
\hline 40 & $36-1,107-108$ & + & - & + & $=$ & - & - & \\
\hline 41 & $37-1,108-110$ & + & + & + & $=$ & - & - & \\
\hline 42 & $38-1,73-74$ & + & + & + & - & - & - & \\
\hline 43 & $38-2,7$ & + & - & + & $=$ & - & + & $\mathrm{Zr}=\mathrm{Cr}+\mathrm{Ti}++$ \\
\hline 44 & $38-2,14$ & + & + & + & + & - & - & \\
\hline 45 & $38-2,31$ & + & - & $=$ & + & + & + & \\
\hline
\end{tabular}

Site 213

\begin{tabular}{|c|c|c|c|c|c|c|c|c|}
\hline 46 & $1-1,5-7$ & + & + & + & $=$ & - & - & $\mathrm{Br}+$ \\
\hline 47 & $1-1,70-72$ & + & + & + & $=$ & - & - & $\mathrm{Br}+$ \\
\hline 48 & $2-5,49-51$ & + & + & + & $=$ & - & - & $\mathrm{Br}+$ \\
\hline 49 & $3-1,30-32$ & + & + & + & $=$ & - & - & $\mathrm{Br}+$ \\
\hline 50 & $3-6,19-21$ & ++ & ++ & + & ++ & ++ & - & $\mathrm{Cr}++$ \\
\hline 51 & $8-3,10-12$ & + & + & + & $=$ & - & - & \\
\hline 52 & $8-6,140-142$ & + & + & + & $=$ & - & - & \\
\hline 53 & $9-6,80-82$ & + & + & + & $=$ & - & - & \\
\hline 54 & $10-3,70-72$ & + & + & + & $=$ & - & - & \\
\hline 55 & $11-4,72-74$ & ++ & + & $=$ & + & + & - & \\
\hline 56 & $13-3,80-81$ & + & + & + & + & + & + & \\
\hline 57 & $14-2,70-72$ & + & + & + & - & - & - & \\
\hline 58 & $16-4,145-147$ & + & + & + & + & ++ & + & \\
\hline
\end{tabular}

Note: Value compared to U.S.G.S. standard W1; semiquantitative symbols used in table: - not detected, = same as W1; + higher than W1; ++ much higher than W1. 
the low iron contents at Site 211 and in Core 37 at Site 212.

A comparison of the $\mathrm{Mn}$ and trace element content in Table 2 with other analytical results reported by Drever (1971, p. 966), Cronan (1973, p. 603), and Bostrom et al. (1969), shows there is no consistent enrichment of these elements in every instance, though some enrichment of one or other trace elements is apparent if the total iron content is particularly high. So far as Sites 212 and 213 are concerned, the only possible enrichment of another element in the most iron-rich zone is the higher $\mathrm{Zn}$ value at Site 212. All other element values in the basal iron-oxide facies are comparable with those of more typical deep-sea clays higher in the sedimentary column.

At Site 213 the iron enrichment is restricted to clay beds, and the interbeds of calcareous ooze show no more visually detectable iron oxide than is typical for such material. At Site 212 slightly metamorphosed limestone trapped between basalt pillows shows no iron enrichment. At Site 211 clayey calcareous ooze was recovered from a 16-meter interval (Cores 12-14) between basaltic basement and a sill (see Chapter 2), and this sediment shows a pronounced reddish to orange brown fine banding on a 1-5 $\mathrm{mm}$ scale. However, two samples analyzed from this interval showed no evidence of any mineralization; even the sample (Core 12) taken from the dusky red zone immediately below the sill was not enriched in iron.

The $\mathrm{K}_{2} \mathrm{O}$ content in this zone is particularly high (Table 3 ) and may be genetically linked to the relatively high $\mathrm{K}_{2} \mathrm{O}$ content in the diabase sill compared with the other basalts at Sites 211,212, and 213 (Hekinian, Chapter 17).

All the authors listed previously who have described basal iron-oxide facies in DSDP cores have attributed their origin to volcanic hydrothermal exhalations following the Bostrom and Peterson (1966) model for the East Pacific Rise. A similar explanation is invoked for this facies in the Leg 22 sites.

The absence of significant iron enrichment in the calcareous sediments at the base of Site 211, in the metamorphed limestone between basalt pillows at Site 212, and in interbeds of calcareous ooze at Site 213 supports the hypothesis that the ferruginous material in the clay beds is syngenetic with the sediment and thus has not been introduced by permeation from below. Also, if the original source of the iron was in the basalts, a depletion of $\mathrm{Fe}$ might be expected in the latter. The analyses of igneous rocks given in Table 4 certainly do not show evidence of such a depletion. However, so few analyses may not be conclusive because Corliss (1970) has pointed out that a depletion of $\mathrm{Fe}, \mathrm{Mn}, \mathrm{Co}$, and rare earth elements only occurs in the holocrystalline interiors of submarine flows relative to the rapidly cooled margins. The two samples analyzed from Site 213 did, however, come from the fresher phaneritic portion of pillow lavas (see Hekinian, Chapter 17, fig. 2). The sample from the diabase in Site 211 came from the center of the sill, but that from the amphibolite in Core 15 of Site 211 was from the aphanitic zone. In all instances, though, the iron content is remarkably uniform. This provides strong support to the argument that the iron of the basal sediment facies has not been derived directly from the closely associated volcanic rocks.

\section{Contact Zones Between Chalk and Clay in Site 212}

One sample from each of the three reduced grayish blue-olive green clay intervals adjacent to chalk units in Site 212 was analyzed (Cores 15-1, 23-5, 27-1 in Table 2). Details of the stratigraphic sequence of each sample can be seen on the core forms given in the site report (Chapter 3). These clays show very low Mn values, but no other characteristics are common to all three. Most striking is the high nickel content of $2730 \mathrm{ppm}$ in one sample, and associated with this are slightly higher $\mathrm{Cu}$ and $\mathrm{Pb}$ values.

In addition to the sample in the reduced zone in Core 15 , a sample was also analyzed from the more typical brown clay $34 \mathrm{~cm}$ below. Comparing the two analyses, the reduced zone is depleted in $\mathrm{Fe}$ and $\mathrm{Mn}$ and enriched in $\mathrm{Cr}$, $\mathrm{Cu}, \mathrm{Ni}, \mathrm{Pb}$, and $\mathrm{V}$.

\section{Dark Brown Mn-rich Layers in Site 213}

Cores 3 through 6 recovered from 18 to 50 meters below the sea floor at Site 213 contain common thin layers of dark to very dark brown intervals within the diatom ooze sequence. These layers are mostly in the 10 to $30 \mathrm{~cm}$ thickness range and are described on the core forms in the site report (Chapter 4) as Mn-Fe-rich layers. The analysis of one sample from such a layer in Core 3 compared with two other samples of siliceous ooze from Cores 1 and 2 confirms that these layers are very rich in $\mathrm{Mn}-$ nearly $8 \%$ compared to $<1 \%$. The iron content is, however, lower than usual, as is the Ti value. Along with the high Mn, considerable enrichment of $\mathrm{Cu}$ and $\mathrm{V}$ is evident (Table 2 and Figure 2).

\section{Variation Downhole of $\mathrm{Fe}, \mathrm{Mn}$, and Trace Elements}

With the exception of the samples taken in unusual sediment types for the specific studies mentioned above, the brown clays analyzed show very little variation in the relative proportions of the trace elements and $\mathrm{Fe}$ and $\mathrm{Mn}$ contents downhole. Typical ranges of values for the three sites (in ppm) are:

\begin{tabular}{|c|c|c|c|c|c|}
\hline Site & $\mathrm{Cr}$ & $\mathrm{Cu}$ & $\mathrm{Ni}$ & $\mathrm{Pb}$ & $\mathrm{Ti}$ \\
\hline 211 & $40-50$ & $100-300$ & $100-150$ & 50 & $6000-7000$ \\
\hline 212 & $50-90$ & $100-400$ & $100-400$ & $30-100$ & $6000-8000$ \\
\hline \multirow[t]{5}{*}{213} & $35-60$ & $200-500$ & $100-500$ & $30-70$ & $3500-6000$ \\
\hline & Site & V & $\mathrm{Zn}$ & $\mathrm{Fe}$ & Mn \\
\hline & 211 & $200-300$ & $150-160$ & $4.0-7.0$ & $<1$ \\
\hline & 212 & $200-350$ & $150-200$ & $4.5-8.5$ & $<2$ \\
\hline & 213 & $150-250$ & $100-200$ & $3.0-7.0$ & $<2$ \\
\hline
\end{tabular}

\section{ACKNOWLEDGMENTS}

The X-ray fluorescence and atomic absorption analyses were carried out in the Scripps Institution of Oceanography analytical facility under the supervision of R. Laborde. The author would also like to extend his appreciation to $R$. Fitzgerald for time on the X-ray fluorescence unit used in this study. Particular thanks are extended to M. Sangstrom who prepared all samples and also operated the atomic absorption unit. 
TABLE 2

Atomic Absorption Analy ses ${ }^{a}$

\begin{tabular}{|c|c|c|c|c|c|c|c|c|c|c|c|}
\hline $\begin{array}{l}\text { Lab } \\
\text { No. P }\end{array}$ & $\begin{array}{l}\text { Site, Core, } \\
\text { Interval } \\
\text { (cm) }\end{array}$ & $\mathrm{Cr}$ & $\mathrm{Cu}$ & $\mathrm{Fe}$ & $\mathrm{Mn}$ & $\mathrm{Ni}$ & $\mathrm{Pb}$ & $\mathrm{Ti}$ & V & $\mathrm{Zn}$ & Visual Core Description \\
\hline \multicolumn{12}{|c|}{ Site 211} \\
\hline 1 & $1-1,14-16$ & 44 & 302 & 40,500 & 10,900 & 150 & 47 & 6,200 & 216 & 157 & Dark yellowish brown diatom-rich clay \\
\hline 2 & $10-\mathrm{CC}$ & 51 & 123 & 72,500 & 602 & 130 & 51 & 6,800 & 311 & 155 & Moderate brown and dusky yellowish brown clay \\
\hline 6 & $12-2,122-124$ & 65 & 44 & 48,500 & 2,630 & 100 & 24 & 8,280 & 146 & 107 & Dusky red nanno-rich clay adjacent to sill \\
\hline 12 & $14-1,28-30$ & 77 & 86 & 52,000 & 950 & 30 & 19 & 9,400 & 154 & 131 & Moderate brown nanno-rich clay $35 \mathrm{~cm}$ above basalt \\
\hline \multicolumn{12}{|c|}{ Site 212} \\
\hline 15 & $2-1,114-116$ & 86 & 378 & 59,500 & 10,900 & 250 & 59 & 7,400 & 284 & 148 & Moderate brown clay with iron-oxide aggregates \\
\hline 17 & $4-1,122-123$ & 81 & 158 & 67,000 & 12,000 & 230 & 95 & 5,960 & 264 & 154 & Mixed nanno ooze and clay \\
\hline 18 & $10-1,32-33$ & 84 & 369 & 86,000 & 17,300 & 320 & 79 & 6,480 & 285 & 176 & Dark brown iron-oxide-rich clay \\
\hline 21 & $15-1,63$ & 108 & 868 & 53,000 & 628 & 2,730 & 118 & 7,150 & 495 & 134 & Grayish blue green claystone mineralized (contact zone below chalk) \\
\hline 23 & $15-1,97-100$ & 78 & 424 & 80,500 & 21,900 & 390 & 85 & 7,060 & 337 & 172 & Iron-oxide clay \\
\hline 24 & $16-2$, shaving & 91 & 358 & 79,000 & 18,100 & 31 & 76 & 7,430 & 330 & 184 & Dusky brown iron-oxide claystone \\
\hline 25 & $18-2,5-6$ & 60 & 221 & 80,500 & 15,500 & 185 & 63 & 6,400 & 313 & 175 & Dusky brown iron-oxide claystone \\
\hline 26 & $23-5,105-107$ & 52 & 168 & 68,000 & 1,260 & 65 & 13 & 5,170 & 203 & 162 & Grayish olive green zeolite-rich clay (contact zone below chalk) \\
\hline 29 & $27-1,128-130$ & 68 & 505 & 42,000 & 485 & 460 & 56 & 7,330 & 389 & 334 & Medium bluish gray (reduced zone $50 \mathrm{~cm}$ below contact zone) \\
\hline 33 & $28-1,61$ & 61 & 164 & 67,000 & 4,320 & 140 & 46 & 6,430 & 339 & 189 & Dark yellowish brown clay \\
\hline 35 & $25-1,71$ & 70 & 217 & 75,000 & 3,610 & 120 & 48 & 8,650 & 263 & 211 & Dark yellowish brown clay \\
\hline 40 & $36-1,107-108$ & 78 & 119 & 59,500 & 9,370 & 140 & 33 & 7,260 & 214 & 177 & Moderate yellowish-brown claystone \\
\hline 41 & $37-1,108-110$ & 47 & 163 & 44,000 & 9,180 & 140 & 12 & 6,200 & 184 & 153 & Moderate reddish brown with brown banding \\
\hline 44 & $38-2,14$ & 73 & 347 & 11,000 & 3,270 & 150 & 12 & 7,180 & 348 & 210 & Grayish brown clay \\
\hline \multicolumn{12}{|c|}{ Site 213} \\
\hline 46 & $1-1,5-7$ & 36 & 292 & 34,000 & 6,430 & 130 & 39 & 3,600 & 162 & 116 & Medium brown clay siliceous ooze \\
\hline 48 & $2-5,49-51$ & 45 & 232 & 39,500 & 1,140 & 130 & 31 & 4,550 & 173 & 108 & Light brown reddish yellow clay siliceous ooze \\
\hline 50 & $3-6,19-21$ & 33 & 1,046 & 20,100 & 78,200 & 290 & 214 & 2,490 & 675 & 108 & Very dark brown manganese-rich diatom ooze \\
\hline 52 & $8-6,140-142$ & 47 & 466 & 47,500 & 9,500 & 260 & 60 & 4,650 & 225 & 140 & Dark brown clay \\
\hline 53 & $9-6,80-82$ & 36 & 480 & 44,000 & 12,800 & 240 & 55 & 4,000 & 188 & 148 & Dark brown clay \\
\hline 54 & $10-3,70-72$ & 35 & 466 & 45,000 & 13,900 & 280 & 52 & 4,080 & 194 & 137 & Dark brown clay \\
\hline 55 & $11-4,72-74$ & 57 & 490 & 59,500 & 21,400 & 500 & 70 & 5,050 & 238 & 175 & Dusky yellowish brown clay (zeolite-rich) \\
\hline 56 & $13-3,80-81$ & 39 & 346 & 64,000 & 18,400 & 420 & 54 & 6,040 & 257 & 201 & Dusky brown iron-oxide-rich clay \\
\hline 57 & $14-2,70-72$ & 50 & 228 & 70,500 & 11,400 & 210 & 61 & 6,270 & 244 & 194 & Moderate brown iron-oxide-rich clay \\
\hline 58 & $16-4,145-147$ & 39 & 523 & 162,000 & 32,000 & 280 & 168 & 5,000 & 713 & 350 & Grayish brown clay-rich iron oxide \\
\hline \multicolumn{12}{|l|}{ Error } \\
\hline & & $\pm 2 \%$ & $\pm 2 \%$ & $\pm 2 \%$ & $\pm 3 \%$ & $\pm 5 \% \mathrm{~b}$ & $\pm 2 \% \mathrm{c}$ & $\pm 7 \%$ & $\pm 2 \%$ & $\pm 2 \%$ & \\
\hline \multicolumn{12}{|c|}{ U.S.G.S. Standards } \\
\hline W1 & found & 118 & 121 & 73,500 & 1,550 & 56 & 11 & 8,500 & 240 & 94 & \\
\hline & range & $90-160$ & $80-150$ & 77,200 & 1,310 & $55-88$ & $5-10$ & 6,300 & $120-320$ & $20-95$ & \\
\hline G2 & found & $\begin{array}{r}12 \\
5-29\end{array}$ & $\begin{array}{r}12 \\
2-17\end{array}$ & $\begin{array}{l}19,500 \\
18,100\end{array}$ & $\begin{array}{l}286 \\
250\end{array}$ & & $\begin{array}{r}35 \\
15-43\end{array}$ & $\begin{array}{l}3,500 \\
3,000\end{array}$ & $\begin{array}{r}53 \\
26-60\end{array}$ & $\begin{array}{r}90 \\
42-138\end{array}$ & \\
\hline BCR-1 & found & $\begin{array}{r}3-29 \\
16\end{array}$ & & 87,100 & 1,410 & & & $\begin{array}{r}5,000 \\
16,500\end{array}$ & 136 & 136 & \\
\hline & $\begin{array}{l}\text { found } \\
\text { range }\end{array}$ & $8-45$ & $7-33$ & $\begin{array}{l}81,100 \\
89,800\end{array}$ & $\begin{array}{l}1,410 \\
1,375\end{array}$ & & $4-35$ & 13,000 & $120-700$ & 94278 & \\
\hline
\end{tabular}

${ }^{\mathrm{a}}$ All values in $\mathrm{ppm}$.

bexcept for values less than 200 ppm, perhaps $\pm 10 \%$.

${ }^{c}$ Except for values less than $20 \mathrm{ppm}$. 


\section{REFERENCES}

Bostrom, K. and Peterson, M. N. A., 1966. Precipitates from hydrothermal exhalations on the East Pacific Rise: Econ. Geol., v. 61, p. 1258.

Bostrom, K., Peterson, M. N. A., Joensuu, O., and Fisher, D., 1969. Aluminum poor ferromanganoan sediments on active oceanic ridges: J. Geophys. Res., v. 74, p. 3261.

Corliss, J. B., 1970. Mid-ocean ridge basalts: Ph.D. thesis, University of California, San Diego.

Cronan, D. S., 1973. Basal ferruginous sediments cored during Leg 16, Deep Sea Drilling Project. In Initial Reports of the Deep Sea Drilling Project, Volume XVI: Washington (U.S. Government Printing Office), p. 601-604.

Drever, J. I., 1971. Chemical and mineralogical studies, Site 66. In Initial Reports of the Deep Sea Drilling Project, Volume VII: Washington (U. S. Government Printing Office), p. 965-975.

Fitzgerlad, R. and Gantzel, P., 1971. X-ray energy spectrometry in the 0.1 to $10 \mathrm{~A}^{\circ}$ range. In Energy dispersion
X-ray analysis: X-ray and electron probe analysis: Am. Soc. Testing Materials, STP 485, p. 3-35.

Lancelot, Y., Hathaway, J. C., and Hollister, C. D., 1972. Lithology of sediments from the western North Atlantic, Leg 11 Deep Sea Drilling Project. In Initial Reports of the Deep Sea Drilling Project, Volume XI: Washington (U. S. Government Printing Office), p. 901-949.

Peterson, M. N. A., Edgar, N. T., von der Borch, C. C., and Rex, R. W., 1970. Cruise leg summary and discussion. In Initial Reports of the Deep Sea Drilling Project, Volume II: Washington (U. S. Government Printing Office), p. 413-427.

von der Borch, C. C. and Rex, R. W., 1970. Amorphous iron oxide precipitates in sediments cored during Leg 5, Deep Sea Drilling Project. In Initial Reports of the Deep Sea Drilling Project, Volume V: Washington (U. S. Government Printing Office), p. 541.

von der Borch, C. C., Nesteroff, W. D., and Galehouse, J. S., 1971. Iron-rich sediments cored during Leg 8 of the Deep Sea Drilling Project. 


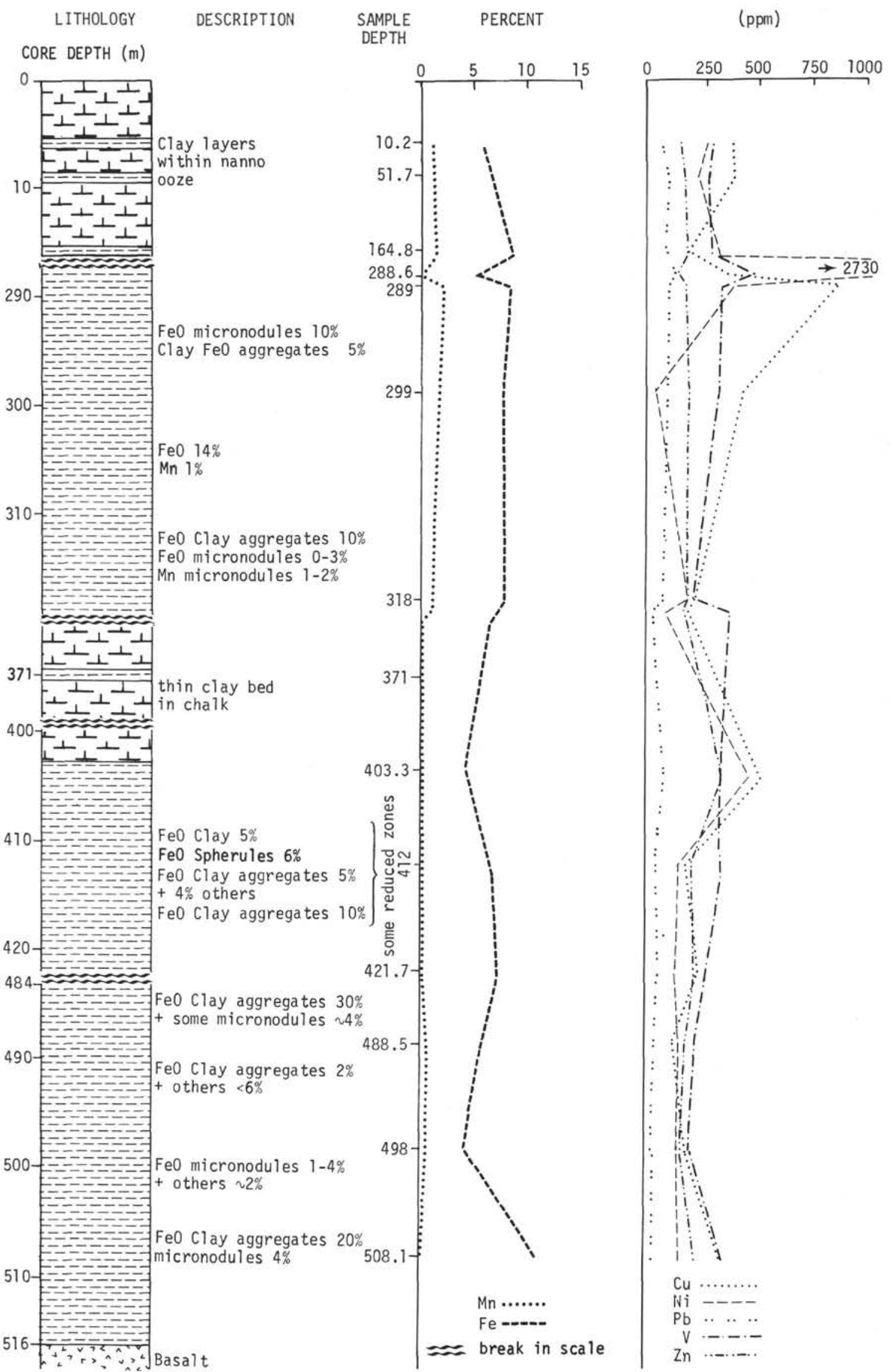

Figure 2. Elemental variation downhole in Site 212. 


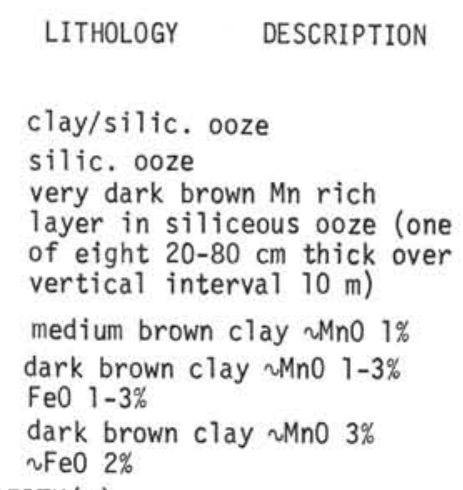
$\operatorname{CORE} \operatorname{DEPTH}(\mathrm{m})$
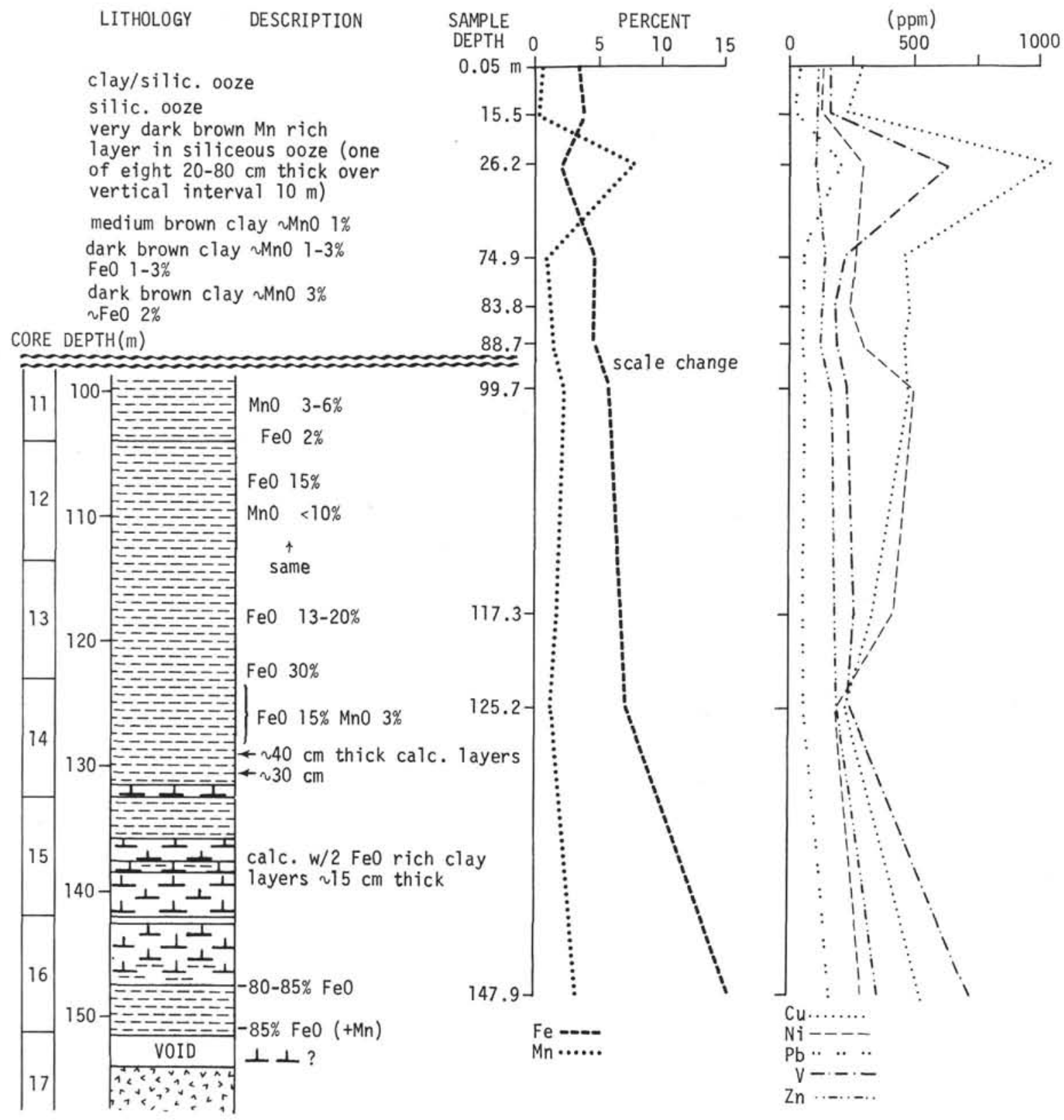

Figure 3. Elemental variation downhole in Site 213. 
A. C. PIMM

TABLE 3

Major Element X-Ray Fluorescence Analyses of Sediments ${ }^{\mathrm{a}}$

\begin{tabular}{|c|c|c|c|c|c|c|c|c|c|c|}
\hline $\begin{array}{l}\text { Core, Section, } \\
\text { Depth in Core } \\
\quad(\mathrm{cm})\end{array}$ & $\mathrm{SiO}_{2}$ & $\mathrm{Al}_{2} \mathrm{O}_{3}$ & $\mathrm{Fe}_{2} \mathrm{O}_{3}$ & $\mathrm{MgO}$ & $\mathrm{CaO}$ & $\mathrm{Na}_{2} \mathrm{O}$ & $\mathrm{K}_{2} \mathrm{O}$ & $\mathrm{TiO}_{2}$ & $\mathrm{P}_{2} \mathrm{O}_{5}$ & $\begin{array}{c}\text { Ignition } \\
\left(\mathrm{CO}_{2}+\mathrm{H}_{2} \mathrm{O}\right)\end{array}$ \\
\hline \multicolumn{11}{|l|}{ Site 211} \\
\hline $\begin{array}{l}12-2,124-128 \\
14-1,65\end{array}$ & $\begin{array}{l}46.15 \\
44.36\end{array}$ & $\begin{array}{l}12.47 \\
11.30\end{array}$ & $\begin{array}{l}6.79 \\
6.94\end{array}$ & $\begin{array}{l}2.16 \\
3.71\end{array}$ & $\begin{array}{l}9.00 \\
7.84\end{array}$ & $\overline{1.47}$ & $\begin{array}{l}7.53 \\
3.62\end{array}$ & $\begin{array}{l}0.90 \\
0.99\end{array}$ & $\begin{array}{l}0.27 \\
0.25\end{array}$ & $\begin{array}{l}13.49 \\
18.30\end{array}$ \\
\hline \multicolumn{11}{|l|}{ Site 212} \\
\hline $\begin{array}{l}18-1,105-107 \\
35-5,44-45 \\
37-19091 \\
38-298\end{array}$ & $\begin{array}{l}41.70 \\
4712 \\
54.73 \\
45.50\end{array}$ & $\begin{array}{l}15.21 \\
16.08 \\
1315 \\
11.85\end{array}$ & $\begin{array}{r}10.84 \\
10.44 \\
6.84 \\
14.69\end{array}$ & $\begin{array}{l}2.49 \\
2.96 \\
3.31 \\
3.26\end{array}$ & $\begin{array}{l}0.77 \\
0.66 \\
0.88 \\
0.94\end{array}$ & $\begin{array}{l}- \\
- \\
\overline{-} \\
1.41\end{array}$ & $\begin{array}{l}2.04 \\
2.68 \\
2.96 \\
3.47\end{array}$ & $\begin{array}{l}0.70 \\
0.71 \\
0.72 \\
0.87\end{array}$ & $\begin{array}{l}0.36 \\
0.25 \\
0.29 \\
0.38\end{array}$ & $\begin{array}{l}22.59 \\
17.90 \\
16.24 \\
14.32\end{array}$ \\
\hline \multicolumn{11}{|l|}{ Site 213} \\
\hline $\begin{array}{l}9-68485 \\
16-4,138-139\end{array}$ & $\begin{array}{l}44.92 \\
38.39\end{array}$ & $\begin{array}{r}13.83 \\
8.86\end{array}$ & $\begin{array}{r}5.94 \\
19.57\end{array}$ & $\begin{array}{l}3.60 \\
3.48\end{array}$ & $\begin{array}{l}1.32 \\
4.19\end{array}$ & $\begin{array}{l}- \\
-\end{array}$ & $\begin{array}{l}1.62 \\
2.49\end{array}$ & $\begin{array}{l}0.46 \\
0.56\end{array}$ & $\begin{array}{l}0.53 \\
1.14\end{array}$ & $\begin{array}{l}19.96 \\
19.92\end{array}$ \\
\hline
\end{tabular}

${ }^{\mathrm{a}}$ Analysis by P. Cambon, Centre Oceanologique de Bretagne, Brest, France. All values given in percent.

TABLE 4

Trace Element Analysis of Igneous Rock Samples

\begin{tabular}{lrrrrrrrrr}
\hline $\begin{array}{l}\text { Core, Section, } \\
\begin{array}{l}\text { Depth in Core } \\
(\mathrm{cm})\end{array}\end{array}$ & $\mathrm{Ti}$ & $\mathrm{V}$ & $\mathrm{Cr}$ & $\mathrm{Fe}$ & $\mathrm{Co}$ & $\mathrm{Ni}$ & $\mathrm{Cu}$ & $\mathrm{Zn}$ & Rock Type \\
\hline Site 211 & & & & & & & & & \\
& 15,100 & 115 & 75 & 63,600 & 55 & 110 & 21 & 70 & Amphibolite \\
$15-2,0-5$ & 13,280 & 140 & 275 & 73,800 & 65 & 155 & 31 & 80 & Diabase \\
$12-1,143-145$ & & & & & & & & & \\
Site 213 & & & & & & & & & \\
$18-2,101-103$ & 6,060 & 235 & 280 & 74,000 & 90 & 135 & 80 & 75 & Basalt \\
$18-1,144-150$ & 6,180 & 235 & 380 & 73,800 & 90 & 115 & 80 & 85 & Basalt \\
\hline
\end{tabular}

Note: Values given in ppm. 